\title{
The epidemiology of diabetes in Swedish children 0-14 years - a six-year prospective study
}

\author{
G. Dahlquist ${ }^{1}$, L. Blom ${ }^{1}$, G. Holmgren ${ }^{2}$, B. Hägglöf ${ }^{2}$, Y.Larsson ${ }^{3}$, G. Sterky ${ }^{4}$, and S. Wall ${ }^{5}$ \\ ${ }^{1}$ Department of Pediatrics, Karolinska Institute, Sachs' Children's Hospital, Stockholm, ${ }^{2}$ Department of Pediatrics, University Hospital, Umeå, \\ ${ }^{3}$ Department of Pediatrics, University Hospital, Linköping, ${ }^{4}$ Swedish Medical Research Council, Stockholm, and \\ ${ }^{5}$ Department of Social Medicine, University Hospital, Umeå, Sweden
}

\begin{abstract}
Summary. Since 1 July 1977, all newly diagnosed diabetic children in Sweden aged 0-14 years have been reported to a central register. During the first 6 years, 2300 newly diagnosed diabetic children out of a population of 1.6 million children were registered. The degree of certainty was close to $100 \%$. The mean of the yearly incidence rate for the whole 6 year period was 23.6 per 100000 . The prevalence of insulin dependent diabetes mellitus on 1 July 1980 was 1.48 per 1000 and 1.52 on 1 July 1983 . Comparing the first and second 3-year periods, an increase was found (22.7-25.1 per 100000). This increase was consistent when analyzing incidence rates by age, sex, and geographical distribution. Cumulative incidence rates revealed a risk of developing diabetes by the age of 15 years of 3.6 per thousand for boys and 3.2 per thousand for girls. The higher incidence for boys was consistent throughout
\end{abstract}

the study period. Seasonal variations in the incidence rate were also consistent, showing yearly incidence peaks in the autumn and winter months. Incidence peaks were noted for both sexes in the pubertal ages. Age- and sex-standardized morbidity ratios varied significantly within the country. $12.8 \%$ of the probands had a first degree relative with Type 1 diabetes, and it was twice as common that this relative was a father as a mother. The high and rapidly increasing incidence of Type 1 diabetes in a genetically stable population such as Sweden calls for case-control studies directed towards the identification of environmental pathogens.

Key words: Type 1 diabetes, children, epidemiology, incidence, prevalence.
Since 1 July 1977, all newly diagnosed diabetic children in Sweden have been consecutively reported to a central register in Stockholm. An analysis covering the first 3 years [1] revealed a mean annual incidence of 22.7 per 100000 children. While a higher incidence has been reported from Finland, studies from other parts of Scandinavia and the western world show lower incidence rates [2-17]. Compared to a smaller retrospective Swedish study conducted 1970-1975 [18], a small increase in incidence rate (19.6 compared to 22.7 per 100000 ) was noted. It is of special interest to study this tendency prospectively, as several recent reports using different retrospective methods $[2,3,6,11,19-25]$ indicate an increase in the incidence of Type 1 diabetes.

In our previous study, a geographical variation of incidence rates within Sweden was noted. In accordance with several other reports, the first three-year period showed peak incidences in the prepubertal years for both boys and girls. A consistently higher incidence was noted for boys in the younger ( $0-10$ years) age groups. Peak incidence of new cases were reached in the autumn and winter.

The present analysis, covering registered data until 1 July 1983, is aimed at answering the following questions:
1. Is there an increase in the incidence of Type 1 diabetes in Sweden?

2. Can significant geographical variations in incidence rates be found within Sweden?

3. Are previously noted differences in incidence rates by sex, by age and by season stable?

4. To what extent do Type 1 (insulin-dependent) and Type 2 (non-insulin-dependent) diabetes respectively occur in first degree relatives?

\section{Subjects and methods}

In Sweden, all children aged 0-14 years with suspected diabetes are referred to and treated at the pediatric clinics. After diagnosis all children with diabetes are hospitalized during the first 1-3 weeks of illness. In the present study, all 44 pediatric clinics in the 24 counties of Sweden reported their newly diagnosed diabetic patients to a central register in Stockholm. A standardized form was used to record the patients' date of birth, sex, name and address of the hospital, date of diagnosis of diabetes (i. e. the day when the first insulin injection was given) and the presence of Type 1 (insulin-dependent) and/or Type 2 (non-insulin-dependent) diabetes in first degree relatives. Only insulin-treated children are registered. The total number of children in the different age groups and counties were obtained from the Swedish Central Bureau of Statistics. The prevalence of diabetic children as of 1 July 1980 and 1 July 1983 was obtained by a questionnaire answered by all pediatric clinics in Sweden. Every 12-month period, each clinic 


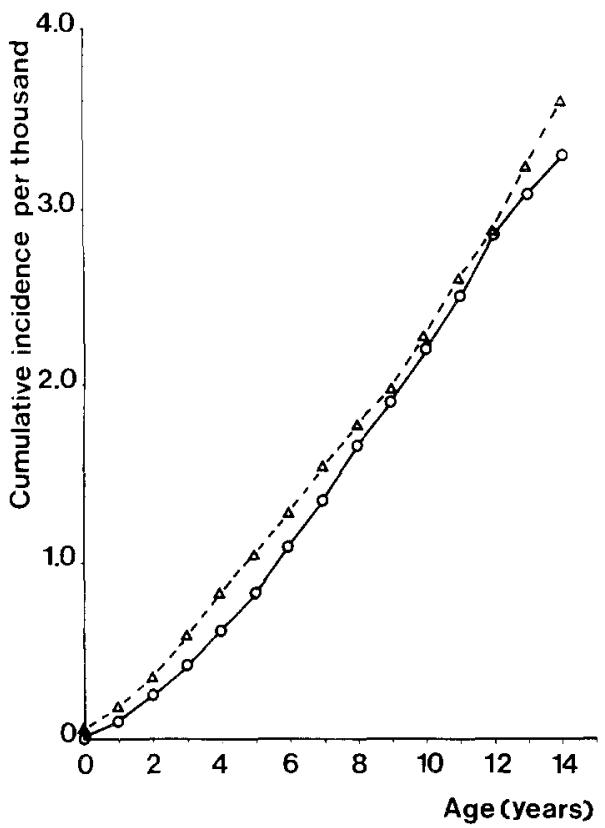

Fig. 1. Cumulative incidence of diabetes by age and sex. $\mathrm{O}-\mathrm{O}$ girls, $\Delta-\cdots-\Delta$ boys

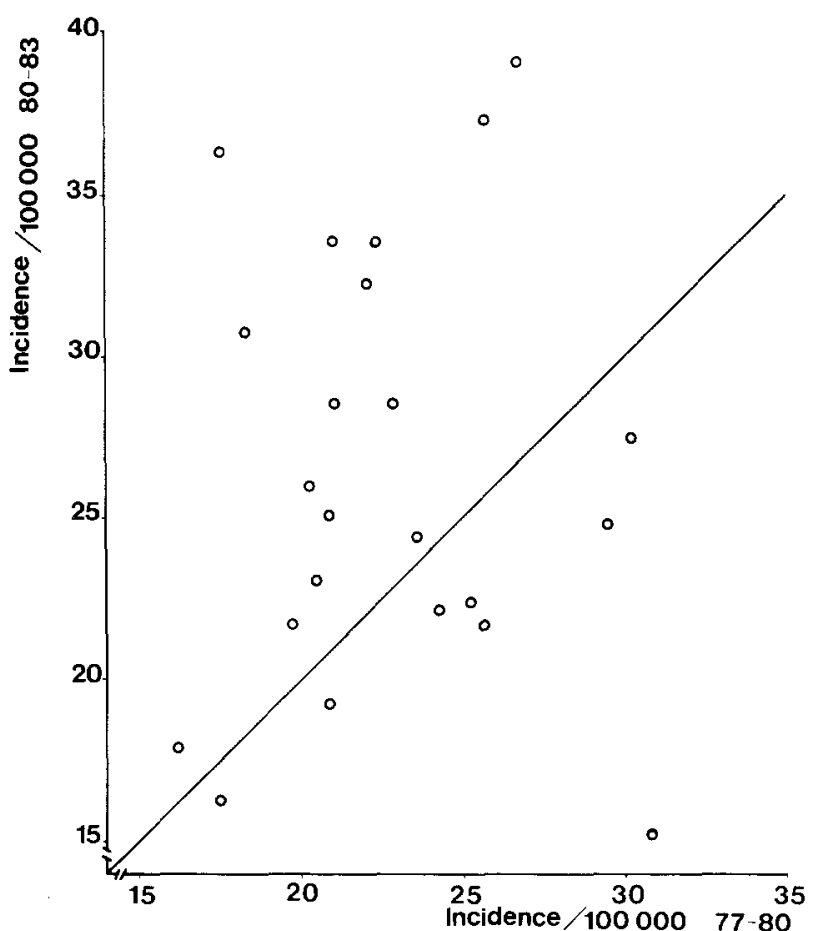

Fig. 2. Scattergram of the mean yearly incidence for the different counties comparing $1977-1980$ to $1980-1983$. The line of identity is indicated in the figure

received a list of the patients reported from their hospital. Nurses were asked to check the list with the local hospital register and to report on possibly missed cases. The percentage correction obtained by these check-ups yielded a mean of $7.5 \%$ of previously non-reported cases $(6.6 \%$ during the first three-year period; $8.5 \%$ during the second 3 -year period). Since the previously missed cases are included in the present analysis, and since it can be assumed that all cases are locally registered, the present study should include $100 \%$ of the diabetic children.

\section{Statistical methods}

A possible increase in incidence between the two three-year periods, 1977-1980 and 1980-1983, has been evaluated in terms of consistency over geographical area (counties), sex, age and season. A linear regression through the origin of diabetes by county has been fitted on a regression plot of referred counties. The slope of the regression line was tested by means of a Student's t-test. Consistency was measured by a product moment correlation coefficient and Spearman's rank correlation coefficient. Comparisons between counties were carried out in terms of standardized morbidity ratios (SMR: s) using the entire country as the standard population. Indirect standardization has been undertaken by age (in 5-year intervals), sex and time period (six 1-year periods). Test-based confidence intervals of $95 \%$ were calculated around SMR values. Age- and sex-specific incidence rates have been translated into cumulative incidence rates (risks) using life table analysis. Sex differences and seasonal variations have been evaluated by means of a chi-square $\left(\chi^{2}\right)$ test.

\section{Results}

Incidence, prevalence and risk of Type 1 diabetes in Swedish children

A total of 2300 children became Type 1 diabetic patients during the 6 -year period studied. Table 1 gives the mean incidence and ranges for all 24 counties over the 6-year period. Prevalence values on 1 July 1980 and 1 July 1983, respectively, are also given. The risk of developing Type 1 diabetes by the age of 15 years in Sweden is 3.6 per 1000 for boys and 3.2 per 1000 for girls (Fig. 1).

\section{Is Type 1 diabetes increasing in Sweden?}

The overall change in incidence from 22.7 to 25.1 per 100000 and year, between the two 3-year periods studied, can be statistically evaluated in several ways. In 15 of the 24 counties the incidence increased. In 8 counties there was a decrease, and 1 remained unchanged. The average difference was +3.5 per 100000 and year, disregarding the varying population sizes. A matched Student's t-test comparing the difference in incidence rate in each county $(\mathrm{df}=23)$ during the two three-year periods is statistically significant $(p<0.05)$. A regression plot shows that the correlation at county level between the two three-year periods is remarkably low (Spearman's rank correlation $=0.15$ ). The equation of a regression line formed by the plot in Figure 2 constrained to pass through the origin yields a slope of the line $\beta=1.12$, which is significantly different from $\beta=1$ ( $p<$ $0.05)(\beta=1$ then corresponds to no change). It may be noted that if only one of the "outlyers" in Figure 2, e.g. the county of Skaraborg, had been omitted, the significance of the trend would increase considerably. The increase by time can also be illustrated by the consistency in the increase during the two 3-year periods with regard to the cumulative rates for girls and boys (Fig. 3) or incidence by age groups (Fig.4).

\section{Can significant geographical variations be found within Sweden?}

To illustrate geographical variation, three equal intervals of incidence have been used, i.e. 17.0-22.3, 


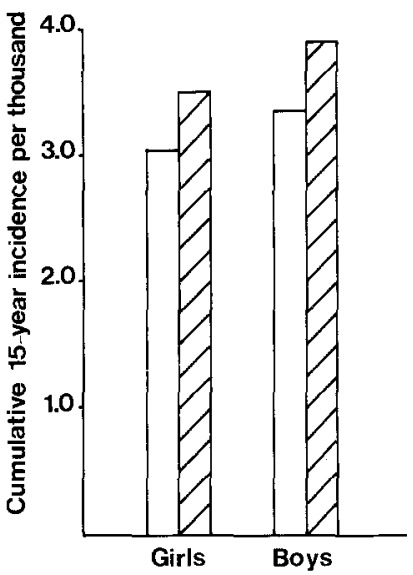

Fig.3. Cumulative incidence at 15 years of age by sex and three-year period. $\square 1977-80, \square 1980-83$

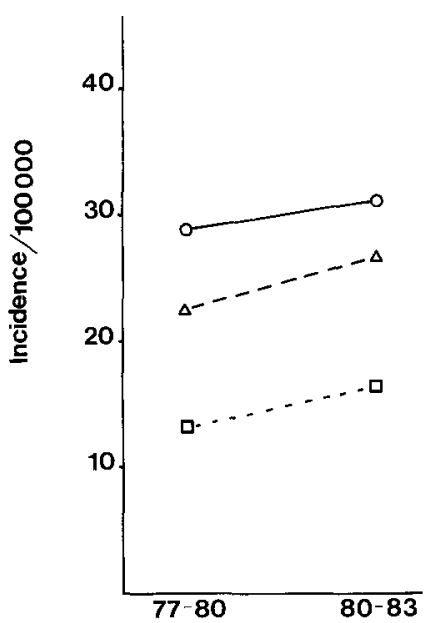

Fig. 4. Incidence by age group for the two three-year periods studied. $[----\square 0-4$ years, $\triangle-\cdots \Delta 5-9$ years, $0-010-14$ years

22.4-27.6 and 27.7-32.8 (Fig. 5). The geographical pattern has been analysed by comparing SMR figures for the 24 counties by sex and by two calendar periods (Fig.6). The results must be interpreted with great caution since the study units represent administrative regions of considerable variation in population size (Table 1). Thus, for some counties the number of cases are rather few. In addition, the urban city areas dominate the standard population to a great extent. The consistency between the two three-year periods is low, as previously displayed in the scattergram in Figure 2. For two geographically close counties, Jönköping [5] (Table 1) and Kalmar [7] (Table 1), the SMR value is well above that of the whole country (Fig.6); this was true for both three-year periods studied. Two counties, Kopparberg and Västerbotten [19, 23] (Table 1), showed consistently low SMR values during both periods. For Stockholm and Malmöhus $[1,11]$ (Table 1), i. e. the two counties with the highest population sizes, the small but significant deviations from SMR must be regarded as less important.

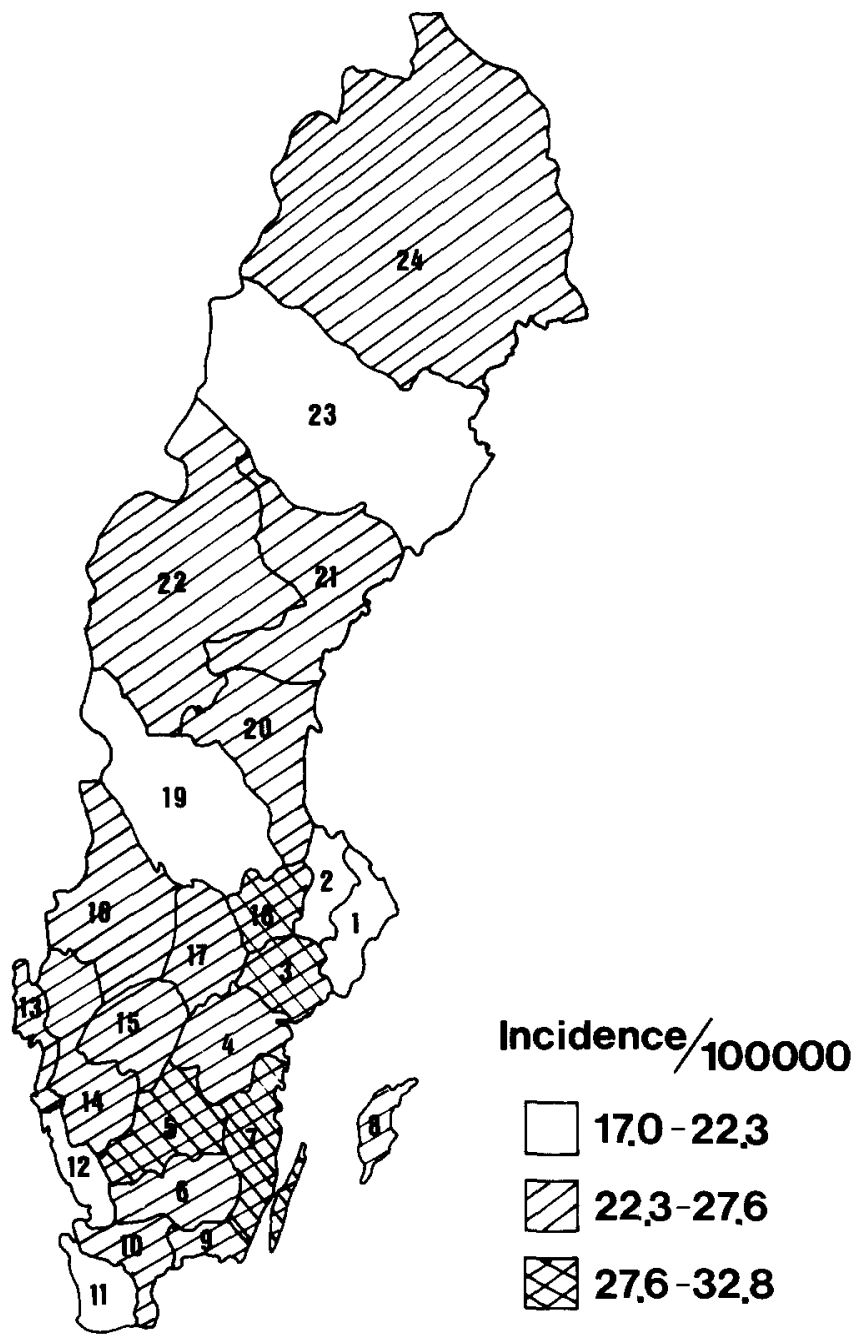

Fig.5. Map of Sweden indicating the geographical variation in incidence rate in a 3-graded scale. The counties are labelled as in Table 1

Are previously noted differences by sex, age and season stable?

Table 2 gives age- and sex-specific incidence rates. The overall incidence is somewhat higher for boys than for girls during both time periods, with an average of 205 new cases occurring yearly among Swedish boys compared to 176 girls $(p<0.05)$. The excess in boys also holds for 21 of the 24 counties. For both three-year periods the age group 5-9 years shows the opposite pattern; i. e. there is a higher incidence for girls. Looking at incidence rates by sex in 1-year age intervals (Fig.7), boys seem to have an increased incidence rate over girls in the youngest ( $0-4$ years) age groups. In the prepubertal period (10-12 years for girls and 12-14 years for boys), the incidence reaches a maximum; a rapid decrease is then seen for the girls. This pattern is consistent for both 3 -year periods. The significant seasonal variation as shown for the first 3-year period in an earlier report [1] is still evident when analysing the 6-year material of 2300 children by sex (Fig. 8) or age (Fig. 9). Even in the 
Table 1. The mean annual incidence of Type 1 diabetes in children 0-14 years of age 1 July 1977-30 June 1983 and prevalence on 1 July 1980 and 1 July 1983 , respectively

\begin{tabular}{|c|c|c|c|c|c|c|}
\hline County area no. & $\begin{array}{l}\text { Total no. of children } \\
0-14 \text { years of age. } \\
\text { Mean of years } 1977-1983\end{array}$ & $\begin{array}{l}\text { Mean yearly } \\
\text { incidence } \\
\text { per } 100000\end{array}$ & \multicolumn{2}{|c|}{ Incidence range } & \multicolumn{2}{|c|}{ Prevalence $/ 1000$ children } \\
\hline 2. Uppsala & 51165 & 21.8 & 15.4 & 31.4 & 1.26 & 1.42 \\
\hline 3. Södermanland & 51334 & 28.9 & 17.7 & 35.8 & 1.62 & 1.47 \\
\hline 4. Östergötland & 78544 & 24.0 & 18.9 & 28.1 & 1.79 & 1.27 \\
\hline 5. Jönköping & 62054 & 32.8 & 15.5 & 49.6 & 1.71 & 1.88 \\
\hline 8. Gotland & 11228 & 26.7 & 8.6 & 54.0 & 0.71 & 1.38 \\
\hline 9. Blekinge & 30585 & 24.0 & 10.1 & 36.3 & 1.71 & 1.70 \\
\hline 10. Kristianstad & 56604 & 23.0 & 13.9 & 26.6 & 1.17 & 1.21 \\
\hline 11. Malmöhus & 141544 & 19.9 & 14.0 & 26.1 & 1.30 & 1.58 \\
\hline 12. Halland & 48869 & 20.1 & 12.2 & 29.0 & 1.48 & 1.32 \\
\hline 13. Göteborg och Bohus & 130928 & 25.6 & 19.5 & 35.6 & 1.43 & 1.62 \\
\hline 18. Västmanland & 52793 & 27.8 & 18.2 & 43.0 & 2.65 & 1.88 \\
\hline 19. Kopparberg & 54547 & 17.1 & 13.0 & 22.0 & 1.24 & 1.15 \\
\hline 20. Gävleborg & 54698 & 24.4 & 17.4 & 36.7 & 1.30 & 1.80 \\
\hline 21. Västernorrland & 50955 & 27.1 & 17.2 & 35.1 & 1.30 & 1.55 \\
\hline 22. Jämtland & 24922 & 24.7 & 11.8 & 40.3 & 1.75 & 1.20 \\
\hline 23. Västerbotten & 48938 & 17.0 & 12.2 & 23.3 & 1.41 & 1.47 \\
\hline 24. Norrbotten & 55082 & 23.6 & 17.1 & 29.6 & 1.31 & 1.62 \\
\hline Total & 1625681 & 23.6 & 22.6 & 25.6 & 1.48 & 1.54 \\
\hline
\end{tabular}

youngest ( $0-5$ years) age group there is a slightly decreased incidence rate during the summer months.

\section{What is the occurrence of Type 1 and Type 2 diabetes in parents?}

Of the probands, $12.8 \%$ had a first degree relative with Type 1 (insulin-dependent) diabetes and $1.5 \%$ had a first degree relative with Type 2 (non-insulin-dependent) diabetes. Table 3 gives the distribution of parents with Type 1 diabetes for proband girls and boys. The chance of having a father with Type 1 diabetes was approximately twice the chance of having a mother with Type 1 diabetes, but there was no difference by sex of probands in this respect. Looking at age at onset (5-year intervals) and seasonality, no difference was found between probands with first degree relatives with Type 1 diabetes and those without such relatives.

\section{Discussion}

In Sweden, all newly diagnosed diabetic children up to 15 years of age have been referred to pediatric clinics; this at least 20 -year-old tradition has repeatedly been officially recommended by Swedish health care programs for diabetic patients [26,27]. The possibility that a child with onset of diabetes below the age of 15 years could have been treated without any contact with a pediatric clinic during the past decade, although it may exist, must be regarded as exceptional in Sweden. Since

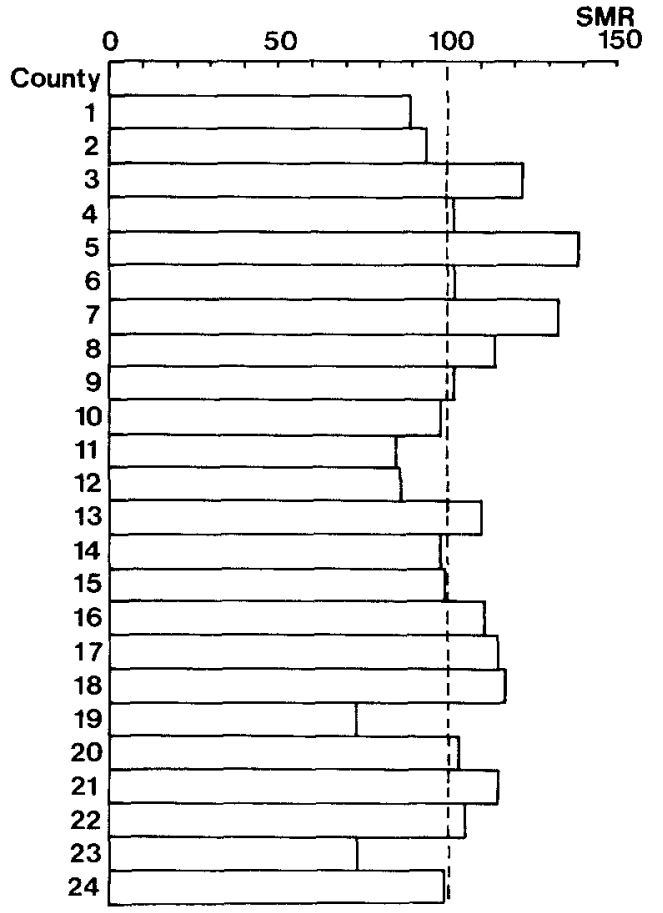

Fig. 6. Standardized morbidity ratios for diabetes by counties. The counties are labelled as in Table 1

all pediatric departments in Sweden take part in the central registration of diabetic children, and as an additional $3-10 \%$ of missed cases obtained from the local registers were included, we can assume to have reached a level of certainty close to $100 \%$. 
Table 2. Age- and sex-specific incidence rates 1977-1983

\begin{tabular}{|c|c|c|c|c|c|c|}
\hline Age (years) & \multicolumn{3}{|l|}{ Girls } & \multicolumn{3}{|l|}{ Boys } \\
\hline 0 & 46153 & 1 & 0.4 & 48559 & 16 & 5.5 \\
\hline 1 & 47041 & 25 & 8.9 & 49336 & 41 & 13.9 \\
\hline 2 & 47917 & 38 & 13.2 & 50268 & 49 & 16.2 \\
\hline 5 & 51787 & 67 & 21.6 & 54387 & 69 & 21.1 \\
\hline 6 & 53183 & 82 & 25.7 & 55838 & 83 & 24.8 \\
\hline 7 & 54018 & 88 & 27.2 & 56611 & 85 & 25.0 \\
\hline 8 & 54218 & 99 & 30.4 & 56922 & 83 & 24.3 \\
\hline 9 & 54437 & 80 & 24.5 & 57120 & 70 & 20.4 \\
\hline 10 & 55280 & 99 & 29.8 & 58110 & 107 & 30.7 \\
\hline 11 & 56098 & 114 & 33.9 & 59036 & 111 & 31.3 \\
\hline
\end{tabular}

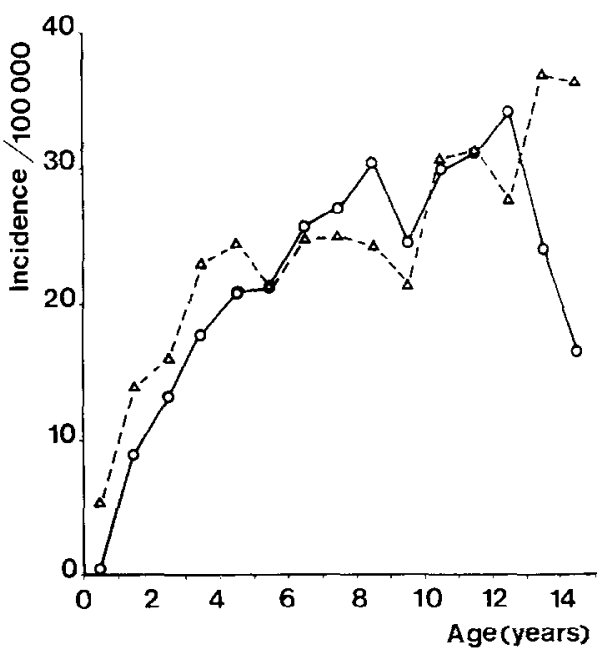

Fig.7. Age-specific incidence of diabetes by sex. $\mathrm{O}-\mathrm{O}$ girls, $\triangle \cdots \triangle$ boys

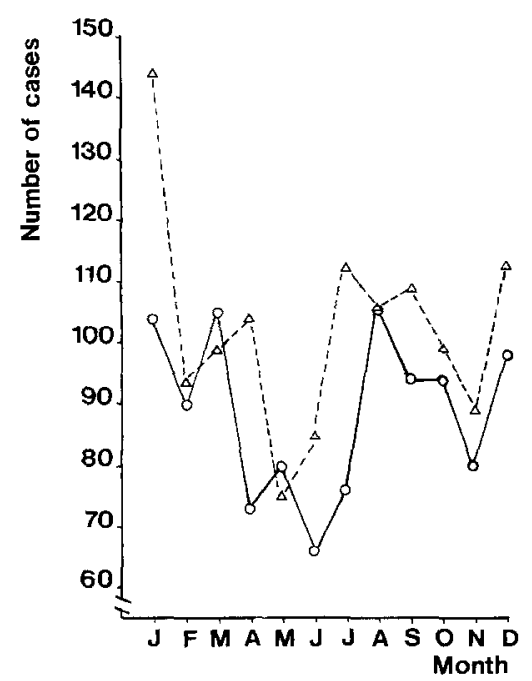

Fig. 8. Seasonal variation at onset of diabetes for 2300 diabetic children by sex. $O \longrightarrow O$ girls, $\triangle \cdots \Delta$ boys

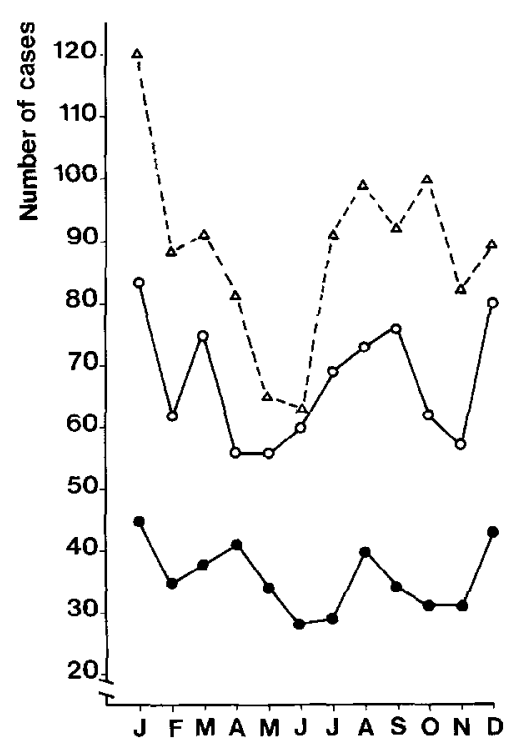

Fig. 9. Seasonal variations of 2300 new cases of diabetes by age group. - 0-4 years, $O-O 5-9$ years, $\Delta-\Delta 10-14$ years

Table 3. Distribution of mothers and fathers with Type 1 diabetes. Figures within brackets denote number of diabetic patients

\begin{tabular}{llcc}
\hline Rrobands & Melatives & Fathers & Total \\
\hline Girls (1068) & 24 & 58 & 82 \\
Boys (1232) & 32 & 73 & 105 \\
\hline Total (2300) & 56 & 131 & 187 \\
\hline
\end{tabular}

This high level of certainty may account for part of the observed high incidence of childhood diabetes in Sweden. However, Norway [3] and Denmark [4] reported studies with levels of certainty well above $90 \%$. The great differences between Sweden and these countries, by comparison, must depend on other factors. In genetically similar Caucasian populations like the Scandinavians [28], environmental factors such as climate or socioeconomic conditions, diet, etc. must be considered. 
The high incidence of childhood diabetes in Sweden becomes even more distressing because it tends to rise, according to the present study. An increased incidence of Type 1 diabetes has been indicated in some countries $[2,3,6,11,19-25]$ but not in others $[4,10,12,15,17]$. This discrepancy could partly be due to lack of precision in the different retrospective methods used. Such lack of precision is small in the present study, as we have prospectively followed incidence rates using the same routines and regular yearly check ups. Also, when comparing the incidence rates in the present study with a smaller Swedish study covering the years 1970-1975 [18] the increase seems to be verified.

In a recent publication, Borch-Johnsen et al. [29] suggested an inverse relationship between breast-feeding and occurrence of childhood diabetes. If this is true, a decreased incidence of diabetes would soon be expected, since breast-feeding has increased significantly in Sweden during the last decade [30]. The mechanism behind this association was suggested to be immunological, i. e. the artificially fed infants would not be provided with the same amount of secretory IgA, cytotoxic $T$ lymphocytes and B lymphocytes. Other adverse effects from the use of artificial formulas, e.g. differences in protein content and aminoacid composition must, however, also be considered. In a socioeconomically highly developed society such as Sweden, other nutrional factors to which growing children may be exposed may also play a role. A possible increase in the rate of specific virus infections may also have taken place.

Within Sweden, the significantly higher incidence rates in at least two geographically close counties and the significantly lower rates in two others are at present difficult to explain. In future studies of these geographical areas, possible differences in socioeconomic and other demographic pattern should be analysed.

The seasonal variation showing the highest incidence rates during winter and autumn, and the low incidence during summer, is in agreement with numerous previous reports $[1,2,4,5,18,30-35]$. An association with seasonal variations in viral disease was earlier suggested as an explanation [36]. However, other factors such as seasonal differences in social and thermal stress and different eating habits, as well as possible delay in seeking care during summer vacations, must also be considered. In an attempt to analyse the seasonal incidence pattern in relation to sex, type of onset, age at onset and family history, Gleason et al. [37] found an exaggerated seasonality in a subgroup of children aged $0-14$ years with an acute onset of the disease and without family history of diabetes, whereas no similarity was found between the diabetes incidence pattern and the pattern of viral and bacterial infections. In our study, we found no significant difference in seasonality in diabetic patients with or without a first degree relative with Type 1 diabetes. Several studies $[2,6,11,34]$ indicate a less pronounced seasonality in the youngest children compared to older age groups. Such a pattern was also found in our first three-year study [1]. However, analysing the larger 6-year material we also find a trend to sea- sonality in the youngest age group. Lack of seasonality may therefore be due to the relatively small number of patients in the 0-4 year age group. The repeated findings $[38,39]$ of seasonal variations in fasting plasma glucose in normal man showing a circular annual rhythm with the lowest levels in summer and a significant inverse correlation to temperature, is interesting for the interpretation of both the seasonality of diabetes and the high incidence rates found in Sweden and Finland.

The relative risk of developing diabetes in childhood is significantly higher for boys than for girls, as shown both in the present study and in several others $[1-5,34,35]$. This is especially evident in the youngest age groups; in the prepubertal years, when incidence peaks are found for the boys and girls, the difference is not evident presumably because of the earlier sexual maturation in girls. The higher risk for boys could either be an expression of a higher frequency of genetic risk factors in boys, or of a higher susceptibility to infections $[40,41]$, as suggested by Gleason et al. [37]. Furthermore, exposure to other environmental agents might also be different in boys. If the seasonality pattern is dependent upon an infectious disease pattern, one would expect a more pronounced seasonality for boys than for girls, as actually indicated in the present study [Fig. 8] and in others [42].

In agreement with previous reports [1,5], a high incidence of Type 1 diabetes was found in first degree relatives of the diabetic children. For obvious reasons a high percentage of first degree relatives with Type 1 diabetes were parents. We, as well as others, have also found a higher proportion of diabetic fathers compared to mothers (approximately $2: 1$ ) $[1,19,43,44]$. This finding might simply be dependent on fewer pregnancies in diabetic mothers. However, Warram et al. [44], who studied the incidence of diabetes in offspring of diabetic patients, found a higher frequency of diabetes in the offspring of diabetic men compared to that of diabetic women. A selective perinatal loss of affected offspring of the diabetic mothers is one possibility. The preferential zygotic assortment of paternal HLA haplotype to children as shown by Cudworth et al. [45] might offer another explanation.

Epidemiological studies such as the present one indicate that, in addition to genetically determined factors such as HLA-antigens, sex and growth pattern, other factors such as climate, socioeconomic, nutritional and/or psychological stress factors may also play an aetiological role by possibly interfering with the immunological response to certain viral infections. The high and increasing incidence of Type 1 diabetes in Sweden calls for case-control studies aimed at disclosing such environmental risk factors.

Acknowledgements. This work was supported by grants from the Karolinska Institute and the Swedish Diabetes Association. We also want to thank all pediatricians and nurses who with great ambition sent us the registration forms and returned the check-up lists. 


\section{References}

1. Dahlquist G, Gustavsson KH, Holmgren G, et al. (1982) The incidence of diabetes mellitus in Swedish children 0-14 years of age. Acta Paediatr Scand 71: 7-14

2. Reunanen A, Åkerblom HK, Käär ML (1982) Prevalence and tenyear (1970-1979) incidence of insulin-dependent diabetes mellitus in children and adolescents in Finland. Acta Paediatr Scand 71: 893-899

3. Joner G, Søvik O (1981) Incidence, age at onset and seasonal variation of diabetes mellitus in Norwegian children 1973-1977. Acta Paediatr Scand 70: 329-335

4. Christau B, Kromann H, Christy M, Ortved Andersen O, Nerup J (1979) Incidence of insulin-dependent diabetes mellitus (0-29 years at onset) in Denmark. Acta Med Scand [Suppl] 624: $54-60$

5. Bloom A, Hayes TM, Gamble DR (1975) Register of newly diagnosed diabetic children. Br Med J 3:580-583

6. Patterson CC, Thorogood M, Smith PG, Heasman MA, Clarke JA, Mann JI (1983) Epidemiology of Type 1 (insulin-dependent) diabetes in Scotland 1968-1976: Evidence of an increasing incidence. Diabetologia 24: 238-243

7.-Lestradet H, Besse J (1977) Prevalence et incidence du diabète juvenile insulino-dependant en France. Diabéte Metab (Paris) 3: 229-234

8. Pinelli L, Tato L, Andretta A, Gaburro D (1977) The epidemiology of childhood diabetes mellitus in north-east Italy. Bulletin of the international study group on diabetes in children and adolescents $1: 6-9$

9. Teuscher A, Lüscher R, Zuppinger K, Moser H (1975) Frequency of juvenile diabetes in Switzerland. In: Gutsche H, Holler HD (eds) Diabetes epidemiology in Europe. Thieme, Stuttgart, pp 34-35

10. Kalafatić Z, Frleta M, Fustar A, et al. (1975) The epidemiology of juvenile diabetes in Croatia. In: Gusche H, Holler HD (eds) Diabetes epidemiogy in Europe. Thieme, Stuttgart, pp 21-27

11. Cohen T (1971) Juvenile diabetes in Israel. Isr J Med Sci 7: $1558-1561$

12. LaPorte RE, Fischbein HA, Drash AL, et al. (1981) The Pittsburgh insulin dependent diabetes mellitus (IDDM) registry: The incidence of insulin-dependent diabetes mellitus in Allegheny County, Pennsylvania (1965-1976). Diabetes 30: 279-284

13. Palumbo PJ, Elveback LR, Chu C-P, Connolly DC, Kurland LT (1976) Diabetes mellitus: Incidence, prevalence, survivorship and causes of death in Rochester, Minnesota, 1945-1970. Diabetes 25: 566-573

14. Kyllo CJ, Nuttall FQ (1978) Prevalence of diabetes mellitus in school-age children in Minnesota. Diabetes 27: 57-60

15. West R, Belmonte MM, Colle E, Crepeau MP, Wilkins J, Poirir R (1979) Epidemiologic survey of juvenile-onset diabetes in Montreal. Diabetes 28: 690-693

16. Ehrlich RM, Walsh LJ, Falk JA, Middleton PJ, Simpson NE (1982) The incidence of Type 1 (insulin-dependent) diabetes in Toronto. Diabetologia 22: 289-291

17. Crossley JR, Upsdell M (1980) The incidence of juvenile diabetes mellitus in New Zealand. Diabetologia 18: 29-34

18. Sterky G, Holmgren G, Gustavsson KH, et al. (1978) The incidence of diabetes mellitus in Swedish children 1970-1975. Acta Paediatr Scand 67: 139-143

19. Hägglöf B, Holmgren G, Wall S (1982) Incidence of insulin-dependent diabetes mellitus among children in a North-Swedish population 1938-1977. Hum Hered 32: 408-417

20. Sultz HA, Schlesinger ER, Mosher WE, Feldman JG (1972) Childhood diabetes mellitus. In: Longterm childhood illness. University of Pittsburgh Press, Pittsburgh, pp 223-248

21. North AF, Gorwitz K, Sultz HA (1977) A secular increase in the incidence of juvenile diabetes mellitus. J Paediatr 91 : 706-710

22. Stewart-Brown S, Haslum M, Butler N (1983) Evidence for increasing prevalence of diabetes mellitus in childhood. Br Med $\mathbf{J}$ 286: $1855-1857$
23. Craig JO, Ford JA, McCuish AC (1983) Rising incidence of childhood diabetes. Br Med J 1: 639

24. Scott-Samuel A (1977) Rising incidence of childhood diabetes. $\mathrm{Br}$ Med J 1: 840

25. Green A, Andersen PK (1983) Epidemiological studies of diabetes mellitus in Denmark: 3. Clinical characteristics and incidence of diabetes among males aged $0-19$ years. Diabetologia 25: 226-230

26. Luft R (ed) (1977 and 1982) Underlag till vårdprogram för diabetes. Socialstyrelsens Vårdprogramnämnd, Stockholm

27. Förslag till vårdprogram för barn- och ungdomsdiabetes (1982) SPRI Rapport: 104

28. Svejgaard A, Platz P, Ryder LP (1980) Insulin-dependent diabetes mellitus. In: Ferasaki PI (ed) Histocompatibility testing 1980. University of California Press, Los Angeles, pp 638-656

29. Boch-Johnson K, Joner G, Mandrup-Poulsen T, Christy M, Zachau-Christiansen B, Nerup J (1985) Relationship between breast feeding and incidence rates to insulin-dependent diabetes mellitus - a hypothesis. Lancet (in press)

30. Hofvander Y, Sjölin S (1979) Breast feeding trends and recent information activities in Sweden. Acta Paediatr Scand [Suppl] 275: 122-125

31. Adams SF (1926) The seasonal variation in the onset of acute diabetes. Arch Intern Med 37: 861-864

32. Macmillan DR, Kotovan M, Zeidner D, Hafezi B (1977) Seasonal variation in the onset of diabetes in children. Pediatrics 59: 113-115

33. Durruty P, Ruiz F, Garcia de los Ríos M (1979) Age at diagnosis and seasonal variation in the onset of insulin-dependent diabetes in Chile (Southern Hemisphere). Diabetologia 17: 357-360

34. Fleegler FM, Rogers KD, Drash A, Rosenbloom AL, Travis LB, Court JM (1979) Age, sex and season of onset of juvenile diabetes in different geographic areas. Pediatrics 63: 374-379

35. Fishbein HA, LaPorte RE, Orchard TJ, Drash AL, Kuller LH, Wagener DK (1982) The Pittsburgh insulin-dependent diabetes mellitus registry: Seasonal incidence. Diabetologia 23: 83-85

36. Gamble DR, Taylor KW (1969) Seasonal incidence of diabetes mellitus. Br Med J 3: 631-633

37. Gleason RE, Kahn CB, Funk IB, Craighead JE (1982) Seasonal incidence of insulin-dependent diabetes (IDDM) in Massachusetts 1964-1973. Int J Epidemiol 11: 39-45

38. Fahlén M, Odén A, Björntorp P, Tibblin G (1971) Seasonal influence on insulin secretion in man. Clin Sci $41: 453-458$

39. Suarez L, Barrett-Connor E (1982) Seasonal variation in fasting plasma glucose levels in man. Diabetologia 22: $250-253$

40. Washburn TC, Medearis Jr DN, Childs B (1965) Sex difference in susceptibility to infections. Pediatrics $35: 57-64$

41. Michaels RH, Rogers KD (1971) A sex difference in immunological responsiveness. Pediatrics 47: 120-123

42. Gray RS, Duncan LJP, Clarke BF (1979) Seasonal onset of insulin-dependent diabetes in relation to sex and age at onset. Diabetologia 17: 29-32

43. Wagener DK, Sachs JM, LaPorte RE, MacGregor JM (1982) The Pittsburgh study of insulin-dependent diabetes mellitus. Risk of diabetes among relatives of IDDM. Diabetes 31: 136-144

44. Warram JH, Krolewski AS, Gottlieb MS, Kahn CR (1984) Differences in risk of insulin-dependent diabetes in offspring of diabetic mothers and diabetic fathers. New Engl J Med 311: 149-152

45. Cudworth AG, Gorsuch AN, Wolf E, Festenstein H (1979) A new look at HLA genetics with particular reference to Type 1 diabetes. Lancet 2: 389-391

Received: 27 February 1985

and in revised form: 3 September 1985

Dr. G. Dahlquist

Sachs' Children's Hospital

Sachsgatan 1

S-11669 Stockholm

Sweden 